\title{
Book Review: Teaching English to Speakers of Other Language: An Introduction
}

\section{Fatemeh Ahmadi Livani ${ }^{1 *} \&$ Hamed Barjesteh ${ }^{1}$}

\footnotetext{
* Correspondence:

lida_ahmadi82@yahoo.com

${ }^{1}$ Department of English language and literature, Islamic Azad University,

Ayatollah Amoli Branch, Amol, Iran
}

Received: 16 March 2018

Revision: 2 May, 2018

Accepted: 19 July 2018

Published online: 20 December 2018

\section{Introduction}

Teaching English to Speakers of Other Language presents teaching techniques and procedures along with the underlying theory and principles and is comprehensible to readers who are new to the field of ELT. David Nunan (2015) proposes rich illustrations of theoretical constructs through providing practical examples of how to develop teaching materials and tasks from sound principles; he also presents content through a different of various textual types including classroom vignettes which show language teaching in action, question and answer sessions. The book consists of twelve concise chapters: Language Teaching Methodology, Learner-Centered Language Teaching, Listening, Speaking, Reading, Writing, Pronunciation, Vocabulary, Grammar, Discourse, Learning Styles and Strategies, and Assessment. 
The main topic of chapter one Language Teaching Methodology, has to do with methods, techniques, and procedures for teaching and learning in the classroom. In this chapter, Nunan (2015) defines the three components of the curriculum 'pie': syllabus design which focuses on content, unlike syllabus design methodology focuses on classroom techniques and procedures for sequencing them; the last one evaluation is concerned with judgment about the quality of the program in the service of the learners. He concludes that these components should be in harmony with one another. He also describes eclectic method, melding of techniques and procedures from more than one method and ultimately expresses it is really no method at all. Writer believes that if a method could be found to work better than any other for learners, the language teaching 'problem' would be solved once and for all.

In chapter two, Learner-Centered Language Teaching, the author defines learner-centeredness as engagement of learners in their own learning by making decisions about what, how to learn, and how to be assessed. Nunan (2015) believes that teaching and learning are in harmony and learners are active participants not passive. Writer also discusses why learning goals are as important as language goals in the learner centered classroom.

In the third chapter, Listening, writer discriminates between top-down and bottom-up listening and discusses background knowledge is used in the comprehension of a message in top down listening, but in bottom up listening, incoming data is applied as a source of information. Nunan (2015), the writer of this chapter, concludes listening is an active process not passive one and he also describes four key principles for teaching listening.

In chapter four, Speaking, Nunan (2015) describes communicative competence and different types of it from different views [Bachman (1990) \& Canale \&Swain (1980)]. He emphasizes on the importance of different real-life tasks to encourage negotiation of meaning (information gaps and jigsaw tasks). Writer also argues for a distinction between 'reproductive' speaking and 'creative' speaking and believes that both reproductive and creative languages are necessary in developing speaking skill.

In chapter five, Reading, the author describes reading as receptive skill and explained two important functions of reading: reading for communication and reading for educational purpose. Three important models of reading are illustrated by the author: bottom-up, top-down, and interactive processing. The most prominent approach to the teaching of reading is called phonics (decoding letters from their written to their aural form and to blend them to gather to form words) which is based on bottom-up model. Nunan (2015) asserts that interactive approach (combination elements of bottom-up and top-down processing) provides the best explanation of the reading process.

Chapter six, Writing, Nunan (2015) discusses the advantages and disadvantages of the product and process approaches to writing, he asserts that product-oriented approaches focus on the final product and process-oriented approaches, on the other hand, focus on the procedures involved in arriving at the final product. The author presents some interpretations to principles of teaching writing related to classroom and real world writing tasks; writer also discusses the concept of contrastive rhetoric and its implications for the writing classroom.

The following chapter addresses pronunciation, which Nunan (2015) considers it as problematic subject. Writer highlights the distinctions between segmental phonology (which deals with the analysis of speech into phonemes and differences in semantic meaning caused by different phonemes) and suprasegmental phonology (which has to do with differences in stress, rhythm, and intonation). The main aim of this chapter focuses on the comprehension problems for the listener which caused by problems of stress, rhythm, and intonation. The author tries to clarify strategies and techniques such as minimal pair drilling for teaching segmental and suprasegmental phonology.

In the next chapter entitled vocabulary, Nunan (2015) provides necessary background information about learning vocabulary with regard to the theory of language and teaching. Words can be classified in various ways: the first and fundamental way is in terms of grammatical functions of the word in a sentence and the next deals with distinction between content words (examples: dog, read, now) and function words (examples: however, but, of). The writer mentions that collocation, lexical phrases, and word lists are the focus of teachers' concerns and describes strategies of vocabulary acquisition such as contextualization of new vocabulary and focuses on most useful vocabularies, the writer also emphasized on repetition as an important strategy for vocabulary learning.

In chapter nine, Grammar, the author commences by brief descriptions of different versions of Communicative Language Teaching (CLT): strong view believes to implicit teaching of grammar in the process of communicative language learning tasks; in contrast, weak view emphasizes on explicit teaching of grammar. Next, Nunan (2013) argued that there were two aspects to the definition of the grammar, "The first is that grammar has to do with how words are formed, and the second is that grammar is all about how words are combined to form sentences" (p.63). 
Writer presents two distinguished types of grammar from grammarians' view: the first one is a prescriptive grammar which describes what is grammatically correct and incorrect and a descriptive grammar is built up by analyzing how speakers actually articulate a language. Nunan (2015) focuses on deductive versus inductive approaches to teaching grammar and demonstrates their advantages and disadvantages, he believes inductive approach is more effective than a deductive approach for all learners in all situations.

Chapter ten, Discourse, shifts attention from four skills' approach to language learning in chapter 3, 4, 5, 6 and three linguistic subsystems of sounds, words, and grammar in chapter 7, 8,9 to discourse. The author explains discourse is systematic but isn't a system and can be studied within the communicative context but linguistic subsystems and skills can be studied independently. The author illustrates four different modes of classroom identified by Walsh (2001) as follows: discourse managerial mode, materials mode, skills and systems mode, and classroom context mode. The author states that register is used as a tool for analyzing discourse and its different components are also presented: field, tenor and mode.

Chapter eleven, learning styles and strategies, the author commences with elaborations on learning styles and strategies and he explains learning style as a habitual way that learners go about learning and learning strategies, and is defined as the "cognitive and communicated process that learners use in order to acquire a language" (p.152). Nunan (2015) highlights the nature of the relationship between learning styles and strategies in that a given style will be associated with particular strategies. He presents a classification of strategies in five broad categories: cognitive, interpersonal, linguistic, affective, and creative.

The author also mentions the result of the investigation carried out by Ken Willing $(1988,1989)$ and his team into the relationship between styles and strategies. They concluded that learning styles and strategy preferences had more to do with personality and cognitive style than first language, ethnicity, or level of education. They also argued that learning styles were highly resistant to change. David Nunan (2015), writer of the chapter, is the writer of many books such as second language teaching and learning (1999), designing tasks for the communicative classroom (1989) and so on.

In final chapter, Assessment, Nunan (2015) defines assessment. In addition to assessment, evaluation is also defined because writer believes assessment is concerned with how well our learners have done, while evaluation is much broader and is concerned with how well our program or course has served the learners. Then, he clarifies the differences between assessment of learning and assessment for learning: in assessment of learning, information is provided for external parties (the teachers, the parents, and the institution), in return, assessment for learning provides information to teachers and students.

Writer explains the distinction between direct and indirect assessment, the indirect-direct distinction is a continuum; in direct assessment, there is a direct relationship between assessment and what learners have to do outside the classroom; in contrary, indirect assessment is done based on inferences of what learners can do. The main publications of the writer of this chapter, David Nunan (2015), are about language teaching, syllabus design, and task based language teaching.

\section{Advantages of the Book}

This textbook is designed to be applicable to a wide range of language teaching contexts and regarded as introduction to TESOL. The writer clarifies practical examples of how to develop teaching materials and tasks from sound principles so they can be helpful to provide rich illustrations of theoretical constructs and useable for designing a coherent, comprehensive language teacher education program. It is difficult not to like the author with clear and comprehensible yet non-trivial, style.

\section{Shortcomings of the Book}

To be sure, there are some weaknesses in the book. It is not suitable to proficient teachers, it cannot provide applicable information for TESOL experts and it is ideally aimed at the novice teachers. The author's aim is to provide information for readers, who are new to the field, as it is mentioned by the writer in the introduction (p.8), and he tries to provide brief explanations about important key terms but in some cases explanations are only useful for those who have background knowledge about topics. 


\section{References}

Bachmann, L. (1990). Fundamentals of language testing. Oxford: Oxford University Press.

Canale, M., \& Swain, M. (1980). Theoretical bases of communicative approaches to language testing and teaching. Applied Linguistics, 1(1), 1-47.

Nunan, D. (1989). Designing tasks for the communicative classroom. Cambridge: Cambridge University Press.

Nunan, D. (1999). Second language teaching \& learning. Boston, MA: Heinle \& Heinle.

Nunan, D. (2013). What is this thing called language? 2nd Edition. New York: Palgrave Macmillan.

Nunan, D. (2015). Teaching English to speakers of other languages: an introduction. New York: Routledge.

Walsh, S. (2001). Characterizing teacher talk in the second language classroom: A process approach of reflective practice. Unpublished Ph.D. thesis, Queen's University of Belfast, Northern Ireland.

Willing, K. (1988). Learning styles in adult migrant education. Adelaide: National Curriculum Resource Centre.

Willing, K. (1989). Teaching how to learn: Learning strategies in ESL. Sydney: National Centre for English Language Teaching and Research. https://trove.nla.gov.au/version/22961517 